\title{
CORRELATION CHART OF LOWER CRETACEOUS ROCKS, MADISON RANGE TO LIMA PEAKS AREA, SOUTHWESTERN MONTANA
}

\author{
B y \\ R.G. Tysdal, T.S. Dyman, and D.J. Nichols
}

\begin{abstract}
Lower Cretaceous strata in southwestern Montana were deposited in a nonmarine facies of the Cordilleran foreland in the west and in a marine shelf facies of the foreland in the east. Some of the strata represent time-equivalent sediments deposited in different environments, and different names have been applied previously to the same strata even within the same area. The four measured sections presented here are in sequences of strata that have been telescoped by thrust faults of Late Cretaceous to early Tertiary age, and facies represented in the measured sections originally were deposited farther apart than they are now. Strata described herein are underlain by the Aptian to Albian(?) Kootenai Formation and are overlain by the Cenomanian to Turonian lower part of the Frontier Formation.

In the Snowcrest Range and Lima Peaks area, strata represented by the two westernmost measured sections are assigned to the Albian Blackleaf Formation, which contains the Flood Member and the overlying volcaniclastic-rich Vaughn Member. The Taft Hill and Bootlegger Members of the Blackleaf Formation, in their type sections near Great Falls, are not recognized by us in southwestern Montana. The two easternmost measured sections represent strata in the Madison, Gravelly, and Greenhorn Ranges, where Albian rocks are assigned to the Thermopolis Shale, Muddy Sandstone, and Mowry Shale. In southwestern Montana the Thermopolis Shale and overlying Muddy Sandstone are lithically equivalent to the Flood Member of the Blackleaf Formation, whereas the Mowry Shale is equivalent to the Vaughn Member. Strata in the Snowcrest Range have characteristics in common with both the eastern and western facies. The geographic location for the
\end{abstract}

change in nomenclature is arbitrary, but is plnced along the axis of the Ruby River valley, which separates the Snowcrest Range from the Greenhorn and Gravelly Ranges.

\section{INTRODUCTION}

Lower Cretaceous rocks in southwestem Mortana represent strata that were deposited in the forc'and basin of the Cordilleran thrust belt in the west and in a shelf facies of the foreland in the east. The strata record cyclic sedimentation during a successic $n$ of marine transgressions and regressions, which were caused by an interaction of source-area tectorism, basin subsidence, and varied rates of sedimentation. The four measured sections are in sequences of strata that have been telescoped by thrust faults of Lara nide age, thus facies represented in the measured sequences were originally deposited farther apart than the, are now. Some of the strata represent time-equiv.? sediments deposited in very different environm?nts, and several names have been applied to the same strata within the same area. Hence, nomenclatural problems of the region represented by the section" are addressed in this report.

Strata equivalent to several formations present on the shelf also can be recognized in the barinal sequences to the west. Facies changes occur from east to west, but the rock units are recognize t as broadly similar. The purpose of this report is to review stratigraphic relationships and nomenclature in the region, and to present a revision of the correlations for the units. These goals are accomplished through the presentation of new data, including measured sections, and reinterpretation of existing data. 


\section{MEASURED SECTIONS}

The locations of the four measured sections are shown on figure 1. The two westernmost measured sections, Lima Peaks and Antone Peak, and the lower part (Warm Springs Creek) of the Greenhorn composite section in the valley between the Greenhorn and Gravelly Ranges, were selected from twelve original descriptive sections released in OpenFile reports by Dyman and others (1984), Dyman (1985a, b), and additional data of Dyman. The upper part (Cow Camp) of the Greenhorn composite section, and the Lincoln Mountain section in the Madison Range, are previously unpublished sections of Tysdal. These four sections record the most diverse strata that we know of in the region. The Lincoln Mountain section is nearly completely exposed, but the Antone Peak section in the southern part of the Snowcrest Range is poorly exposed. The lower and upper parts of the Greenhorn composite section lie within $1.5 \mathrm{mi}(2.5 \mathrm{~km})$ of one another.

The four measured sections and their stratigraphic correlations are presented here using the SRG (Stratigraphic Report Graphic). The SRG is a stratigraphic applications computer program developed by the U.S. Geological Survey and Petroleum Information Corporation of Denver, Colo. The SRG accepts sedimentologic, paleontologic, lithologic, paleoecologic, and nomenclatural data for outcrop sections and cores, and displays these data in a scale-variant format (see "Explanation of measured sections") (Petroleum Information Corporation, 1984; Dyman and others, 1985). The SRG is proprietary to Petroleum Information Corporation, but is available by contract to the U.S. Geological Survey for a variety of research applications.

\section{STRATIGRAPHY}

The eastern two measured sections represent strata of the Madison, Gravelly, and Greenhom Ranges (fig. 1). The Lower Cretaceous rocks in these areas are assigned to the Aptian to Albian(?) Kootenai Formation and the Albian Thermopolis Shale, Muddy Sandstone, and Mowry Shale; lowermost Upper Cretaceous rocks are assigned to the Cenomanian to Turonian lower part of the Frontier Formation. In the Snowcrest Range and Lima Peaks area, represented by the western two measured sections, strata correlative with those formations previously named are assigned to the Aptian to Albian(?) Kootenai Formation, the Albian Blackleaf Formation, and the Cenomanian lower part of the Frontier
Formation. Several different names had been used previously for strata that here are called Blackleaf Formation, but no consistent pattern of nomenclature had been established, in part because of local lithologic and facies changes and the great distance between outcrops and type localities. The decision by Dyman and others (1984) and Dyman (1985a, b, c) to apply the names Blackleaf and Frontier to Cretaceous strata in Beaverhead County and the southwestern part of Madison County, Mont., was made after reviewing the literature and carefully examining the area near Blackleaf Creek, Mont., the type area of the Frontier at Cumberland Gap, Wyo., and additional outcrops (Dyman and Nichols, 1988).

The measured sections bridge areas where different shelf and foreland basin terminology are used currently. The lithic character of the Lower Cretaceous stratigraphic units is very much the same in the Madison, Greenhorn, and Gravelly Ranges. In the Lima Peaks area, however, the lithic equivalents of the eastern units are different and use of the Blackleaf name is appropriate. Strata of the Snowcrest Range, represented by the poorly exposed Antone Peak section, seem to have characteristics more like those of the Lima Peaks section than those of the Greenhorn composite section. Reconnaissance data suggest that the Lower Cretaceous rocks of the Snowcrest Range may change character gradually along the length of the range. Hence, the geographic location for the change in nomenclature is somewhat arbitrary, but is here placed along the axis of the Ruby River valley, which separates the Snowcrest Range from the Greenhorn and Gravelly Ranges (fig. 1). This placement is respectful of historical usage of nomenclature in the Greenhorn and Lima Peaks areas, as well as the differing lithic character of the Lower Cretaceous units in different parts of the region. Lower Cretaceous strata of the eastern part of the Centennial Mountains are judged to have characteristics more in common with the eastem strata than with the Blackleaf rocks. Post-Kootenai Lower Cretaceous strata present in the Exxon and American Quasar boreholes near the western part of the Centennial Mountains (fig. 1) were assigned to the Blackleaf Formation by Perry (1986), but Perry (oral commun., 1987) now believes that strata of the American Quasar borehole (the eastern of the two boreholes) are more representative of facies recognized within the eastern part of the region considered in this report.

Stratigraphic relationships and regional correlations are illustrated in figure 2 . In discussing stratigraphic relationships, we generally proceed from east to west, from shelf to foreland basin. 
All megafossils reported here, including those in cited references, were identified by W.A. Cobban except where otherwise noted. Palynomorphs were identified by D.J. Nichols and are shown in tables 1 and 2.

\section{PREVIOUS WORK}

Early works concerned with the Lower and Upper Cretaceous rocks in southwestern Montana commonly were mapping studies, and they generally left the sequence separated into the Kootenai Formation and an undivided unit of overlying strata. In the general area of the measured sections, strata above the Kootenai were assigned to the "Colorado and Montana formations" (Peale, 1896), "Colorado formation" (Mann, 1954, 1960), "Colorado Shale" (Lowell, 1965), Colorado Group (Klepper, 1950; Christie, 1961; Becraft and others, 1970; Garihan and others, 1983), Blackleaf and Frontier Formations undivided (McBride, 1988), or were neither divided nor named (Swanson, 1950; Brasher, 1950; Sheedlo, 1984). In the Lima area, the Aspen Formation (Scholten and others, 1955; Ryder, 1968; Ryder and Ames, 1970; Skipp and others, 1979), and "Colorado Shale" (Sadler, 1980) also have been used for these strata. The term Colorado Group is not used here. The stratigraphy of the Upper Cretaceous Frontier Formation and correlative strata has not been worked out in the western part of southwestern Montana; hence, facies relationships between the Frontier and Upper Cretaceous rocks of the Colorado Group in northwestern Montana are unknown. The Aspen Formation (Veatch, 1907) is geographically restricted to eastern Idaho and western Wyoming, where it is used in conjunction with the underlying Bear River Formation. Strata described here resemble the Blackleaf Formation in northwestern Montana more than they resemble the Bear River Formation.

The post-Kootenai Lower Cretaceous strata on the eastern side of the Pioneer Mountains, northwest of the area of our sections, were assigned to the "Colorado formation" (Richards and Pardee, 1925; Karlstrom, 1948), left unnamed (Myers, 1952), and later placed in the Colorado Group (Ruppel and others, 1983; Pearson and Zen, 1985; Zen, 1988). We cite these studies because they include some of the earliest work undertaken on Lower Cretaceous strata in southwestern Montana, and indicate that the strata do not readily lend themselves to subdivision. In addition, the Pioneer Mountains area contains strata that were studied in detail by other workers (cited, where appropriate, in following section- of this report) who were specifically concerned with Lower Cretaceous rocks, and who also examined rocks in part of the region of the four measired sections presented in this report.

Many studies divided strata above the Koot?nai into lithofacies, members, or formations. Becruse the names and the strata that workers included diffired from one area to the next, other studies are cited and discussed where applicable in the following sections. We have attempted to cite all relevant university theses, but others of which we were unaware may exist.

\section{KOOTENAI FORMATION}

The Kootenai Formation is discussed briefl:" in this report because it underlies all of our measired sections, and contact relationships with overlying rocks require an understanding of the upper part of the Kootenai. The basal part of each of the meas'red sections shown represents strata of the uppermost part of the Kootenai Formation. In southwestern Montana the Kootenai has been divided into as many as six units (for example, DeCelles, 1986). It typically contains a basal conglomeratic sandstore, a variety of medial sandstone and mudstone strata, and carbonate strata in the upper part. Two unit- of carbonate strata have been recognized regionally, the upper of which contains an abundance of gastropods (Holm and others, 1977). The gastropod limestone is commonly considered to mark the top of the formation in southwestern Montana and is uset in this report.

In the shelf area of southwestern Mont na, gastropods are absent locally from the uppermost carbonate strata, as shown by our studies and the graphic sections of Vuke (1984) in the Mad'son Range. The overlying lower sandstone member of the Thermopolis Shale, or equivalent lithofacies, lacks carbonate beds in the sections examined b" us in the Madison, Greenhorn, and Gravelly Rarges. Klepper (1950) previously had used the gastronod limestone to mark the top of the Kootenai in the Snowcrest Range. The contact is sharp, marks an upward change from nonmarine to marine strata, and is disconformable. In the Lima Peaks $\varepsilon^{\text {rea, }}$ non-gastropod-bearing limestone occurs upsectic 7 of the gastropod limestone. Discontinuous lenses of nodular micritic limestone and calcareous muds'one are interbedded with sandstone and siltstone that are typical of the lower sandstone member of the 
Thermopolis. These strata were assigned to the lower part of the Blackleaf Formation by Dyman and Nichols (1988) because (1) the gastropod limestone is a widespread marker unit that is readily identifiable, (2) the gastropod limestone is readily mappable, and (3) the carbonate beds above the uppermost gastropod limestone are discontinuous and thus do not represent a reliable marker unit.

A late Albian palynomorph assemblage was identified in the uppermost part of the Kootenai Formation in the Lima Peaks section, providing a maximum age for the Blackleaf Formation at this locality (table 1). The assemblage was obtained from dark-gray shale below the uppermost gastropod limestone bed.

\section{BLACKLEAF FORMATION}

The Blackleaf name previously had been used for Lower Cretaceous rocks in southwestern Montana (including the area of the four sections presented here) by Schwartz (1972, 1983), James (1977), and Suttner and others (1981); and in the Lima Peaks area by Perry and others (1983) and Perry (1986). In addition, Dyman and others (1984), Dyman (1985a, b, c), and Dyman and Nichols (1988) used Blackleaf for the western three of the measured sections presented in this report.

In northwestern Montana, Cobban and others (1959) named four members of the Blackleaf Formation, from bottom to top: Flood, Taft Hill, Vaughn, and Bootlegger (fig. 2). Detailed measured sections of these members were presented in Cobban and others (1976). The Flood(?) name has been used in southwestern Montana by Perry and others (1983). Dyman (1985a, b, c), Dyman and Nichols (1988), and Schwartz $(1972,1983)$ used informal names for lithic intervals or units of the Blackleaf Formation. We follow Perry and others (1983) in using the name Flood Member to encompass the lowermost strata of the Blackleaf Formation, consisting of two sandstone units separated by a unit of black shale (the lithic equivalent of the shale member of the Thermopolis Shale). We recognize that the sandstone units of this tripartite member differ in character from those in the type section near Flood Siding in Cascade County, Mont. Preliminary study of correlative sandstone units between Lima Peaks and the Drummond area of central western Montana indicate that their character differs areally, although the tripartite nature still exists. We have not recognized the Taft Hill and Bootlegger Members in southwestern Montana. The
Vaughn Member consists predominantly of nonresistant beds of nonmarine bentonitic mudsteme in pastel shades of gray, green, pink, orange, and brown in the area of our measured sections, although nonbentonitic mudstone is present in the Madison Range. Porcellanitic mudstone, volcaniclastic sandstone and siltstone, and tuff are also present in the study area but are more abundant and form part of a much thicker Vaughn sequence west and northwest of the area of this study.

Lithic units of the Blackleaf Formation of $t^{\text {h }}$ is report are similar to the four lithofacies intervals (designated A, B, C, D) of Schwartz $(1972,1983)$. But, because Schwartz did not publish his measured sections or present them in his dissertation, precine correlation with his lithofacies intervals is difficult. On the other hand, some major differences exist between his descriptions of the four intervals and our observations. For example, descriptive material in Schwartz (1972) makes clear that, as defined by h'm, the upper part of the Blackleaf Formation in sone areas in the Greenhorn Range includes Upper Cretaceous strata that we consider part of the Frontier Formation.

The Blackleaf Formation in the area of the west?m two sections varies in thickness from a maximum of $1,500 \mathrm{ft}(457 \mathrm{~m})$ at the Antone Peak section in the Snowcrest Range to a minimum of $1,394 \mathrm{ft}(425 \mathrm{~m})$ at the Lima Peaks section. Similar thicknesses have been reported in the subsurface near the Lima Peaks section (Perry and others, 1983). Corrected dip-meter data (W.J. Perry, Jr., oral commun., 1985) for the American Quasar Peet Creek Federal 29-1 boreh 1le (fig. 1) suggest a thickness of $1,525 \mathrm{ft}(465 \mathrm{~m})$, a value comparable to the thickness exposed near Lima Peaks.

The lithology, thickness, and other geoloric properties of the members and (or) lithic units of the Blackleaf Formation are discussed below with correlative strata of the Thermopolis Shale, Mudily Sandstone, and Mowry Shale.

\section{THERMOPOLIS SHALE}

The name Thermopolis Shale is used in the Livingston area of southwestern Montana (figs. 1, 2) for a sequence of strata that is composed of thee informal members: a lower sandstone, a mid"le shale, and an upper sandstone (Roberts, 1965, 19\%2). Roberts recognized these members as lithic equivalents of the Fall River Sandstone, the Srull Creek Shale, and the Muddy Sandstone, respectively. 
The lower sandstone also is the lithic equivalent of the "rusty beds" that make up the upper part of the Cloverly Formation in Wyoming; and the middle shale is the lithic equivalent of the Thermopolis Shale. For the southern part of the Madison Range, Witkind (1969) had tentatively made correlations with the rocks of the Livingston area and used the Thermopolis name. In this report, and in Tysdal (in press), we follow the usage for contiguous strata in northwestern Wyoming and use the name Muddy Sandstone for the upper sandstone in the Madison, Greenhorn, and Gravelly Ranges. We follow Roberts (1972) in using the informal name lower sandstone member of the Thermopolis Shale for the lithic equivalent of the Fall River Sandstone and the rusty beds, and shale member of the Thermopolis Shale for the correlative of the Thermopolis Shale in Wyoming. Using either the Fall River or Skull Creek names would entail transposing names across areas of southern Montana for which the Wyomingderived nomenclature now is widely used.

\section{Lower sandstone member of the Thermopolis Shale, and Flood Member of the Blackleaf Formation}

The lower sandstone member of the Thermopolis Shale in the Madison Range is composed of palebrown to rusty colored, fine-grained, crossbedded quartz arenite, and characteristically displays abundant oscillatory ripple marks. The upper few feet of the unit at Lincoln Mountain is composed of maroon to dark-brown siltstone, separated by mudstone layers. The lower contact is sharp and probably is unconformable. Vuke (1984) reported the unit to be almost entirely quartz arenite at some localities. According to Vuke (1984) for the Madison Range, and Schwartz (1972) for the entire region, the sandstone member is marine and was deposited in a shoreface environment. In the Flood Member of the Blackleaf Formation in the two western sections, the lithic equivalent of the lower sandstone member of the Thermopolis consists of green to gray and red calcareous mudstone, quartz- and chert-rich sandstone, and micritic and nodular limestone; these strata were deposited in fluvial, lacustrine, and near-shore marine environments (Dyman and Nichols, 1988).

The lower sandstone member is $121 \mathrm{ft}(37 \mathrm{~m})$ thick at the Lincoln Mountain measured section, and ranges from 55 to $120 \mathrm{ft}$ (17 to $37 \mathrm{~m}$ ) thick within the Madison Range (Vuke, 1984; Witkind, 1969). At the composite Greenhorn section the lower sandstone member is $50 \mathrm{ft}(15 \mathrm{~m})$ thick, and its lithic equivi lent in the lower part of the Flood Member of the Blackleaf Formation at the Lima Peaks section increases to a thickness of $220 \mathrm{ft}(67 \mathrm{~m})$.

In the Madison Range, the lower sandsinne member of the Thermopolis Shale was assignet to the lower part of the Bear River(?) Formatior by Austin and Stoever (1950); Hall (1961) used the n'me "upper sandstone member" of the Kootenai Formation; Hadley (1969a, 1980) used "shale unir". of the Kootenai Formation; Lauer (1967), Ray (19<7), Rose (1967), and Bolm (1969) also placed the sandstone in the upper part of the Kootenai; Wi'-nn (1970) subdivided the unit into a silty sandsione member and an overlying rusty beds member and placed both in the Kootenai; Witkind (15<9) designated the rocks the "sandstone member of the Thermopolis(?) Shale"; Kehew (1971) and Walsh (1971) mapped it with the Thermopolis Shale; Vuke (1984) used the named "rusty beds member of the lower Thermopolis Formation"; and Tysdal and Simons (1985) referred to the unit as the lower ha'f of the Thermopolis Shale.

In the Greenhorn Range and the northernmost part of the contiguous Gravelly and Snowcrest Ran-es, Mann $(1954,1960)$ included sandstone here assigned to the lower sandstone member in the "upner sandstone member" of the Kootenai Formation, and Hadley $(1960,1969 b, 1980)$ used the term "shale unit" of the Kootenai Formation. In the central part of the Snowcrest Range, Gealy (1953) and Zeirler (1954) recognized these clastic rocks as equivalents of the rusty beds and mapped them as part of the Thermopolis Shale. In the southern part of the Snowcrest Range, Keenmon (1950) assigned the sandstone unit to the basal sandstone member of the Bear River(?) Formation. In the southern part of the Gravelly Range, Christie (1961) and Sonderegger and others (1982) mapped the sandstone as the top un: of the Kootenai. In the Centennial Mountains and the southern part of the Gravelly Range, Honkala (15 ${ }^{49}$ ) apparently placed the lower sandstone member in the "Colorado shale." Also in the Centennial Mounte "ns, Kennedy (1947) assigned the sandstone immediately above the gastropod limestone of the Kootenai to the Bear River Formation; Witkind $(1975,1982)$ and Witkind and Prostka (1980) placed this sandstone unit in the Thermopolis(?) Shale. In the Lima area, Dillon (1949) included this sandstone in the F a ar River Formation.

Three molds of Inoceramus comancheanus Cra rin, a species of late Albian age, were found in the urner part of the lower sandstone member of the Thermopolis near Monument Hill in the Gravilly 
Range, about $10 \mathrm{mi}(16 \mathrm{~km})$ south of the Greenhorn composite section (Dyman and Nichols, 1988). Three species of lacustrine ostracods (identified by I.G. Sohn) were reported by Hadley (1980, p. 71-72) from the lower part of the lower sandstone member near the Greenhorn composite section. They are Cypridea wyomingensis Jones sensu Peck 1941, Cypridea anomala Peck 1941, and Eupera onestae (McLearn).

\section{Shale member of the Thermopolis Shale, and shale unit of the Flood Member of the Blackleaf Formation}

In the Madison, Gravelly, and Greenhorn Ranges and the Centennial Mountains, the shale member of the Thermopolis Shale is a marine unit that is composed mainly of black fissile shale, but contains thin beds of sandstone in the uppermost part. The equivalent lithofacies of the Flood Member of the Blackleaf Formation in the Snowcrest Range and Lima Peaks area consists predominantly of mudstone, shale, siltstone, and subordinate fine-grained sandstone and limestone; these strata were deposited in lagoonal to shallow-marine environments (Dyman and Nichols, 1988). The shale member is $39 \mathrm{ft}$ (12 $m$ ) thick at the Lincoln Mountain section, and ranges from about 30 to $300 \mathrm{ft}(10$ to $90 \mathrm{~m})$ thick in the Madison Range (Vuke, 1984; Witkind, 1969). In the area from the Greenhorn and Snowcrest Range sections to the Lima Peaks section, the shale lithofacies ranges from 56 to $240 \mathrm{ft}(17$ to $73 \mathrm{~m})$ thick. At the Lima Peaks section, the shale interval of the Blackleaf is poorly exposed. Dyman and others (1984) originally considered this interval part of their upper clastic lithofacies. Lithology and electric logs from the Exxon Company No. 1 Myers Federal well, located about $8 \mathrm{mi}(11 \mathrm{~km})$ east of the Lima Peaks section (fig. 1), indicate the presence of $46 \mathrm{ft}(14 \mathrm{~m})$ of mudstone and shale in this interval.

Albian palynomorphs have been reported from the shale member in the central part of the Madison Range (Vuke, 1982) and in the area of the Greenhorn Range section (Hadley, 1980). Tysdal (in press) collected the bivalve Inoceramus bellevuensis Reeside from the black shale at several localities within the central part of the Madison Range, and Dyman and Nichols (1988) reported a single mold of Inoceramus comancheanus Cragin (late Albian) at the top of the lithofacies near Monument Hill in the Gravelly Range.

In the Madison Range the shale member was assigned to the upper part of the Bear River(?)
Formation by Austin and Stoever (1950); the name Thermopolis(?) Shale was used by Hall (1961) and the "dark-shale member" by Hadley (1969a, 19?'), both of whom equated it with the black shale unit of the Thermopolis Shale of Wyoming. Lauer (19:7), Ray (1967), Rose (1967), Bolm (1969), Kel ?w * (1971), and Walsh (1971) placed the shale unit in the Thermopolis Shale; and Wilson (1970) used the name Thermopolis Shale for the black shale unit only. Other workers recognized its equivalence to the $S^{\prime}$ ull Creek Shale of Montana, but applied different narmes: basal strata of the upper part of the Thermopoli (?) Shale (Witkind, 1969); upper member of the Thermopolis Formation (Vuke, 1984); and upper part of the Thermopolis Shale (Tysdal and Simons, 19?5).

In the Greenhorn Range and the northernnost parts of the contiguous Gravelly and Snowc-est Ranges, Mann $(1954,1960)$ described the black shale unit and assigned it questionably to the "Colorado Formation." Hadley placed the same unit in the Thermopolis Shale, variously calling it the "mirdle shale member" (Hadley, 1960) and later the "darkshale member" (Hadley, 1980), and recognized its lithic correlation with the Skull Creek Shale. In the central part of the Snowcrest Range, Gealy (1953) and Zeigler (1954) mapped these strata as the Thermopolis Shale. In the southern part of the Snowcrest Range, Keenmon (1950) included ti ase strata within the Bear River(?) Formation. In the southern part of the Gravelly Range, this lithofaries was called "Cretaceous Shale, unnamed" (Sonderegger and others, 1982), and "Colorado shale" (Honkala, 1949). In the Centennial Mountains, Kennedy (1047) mapped the shale as part of the Bear River Formation; Witkind $(1975,1976)$ mapped it as the Bear Rive-(?) Formation, but recognized its correlation with the Thermopolis Shale; Witkind and Prostka (1980) and Witkind (1982) called it the shale member of the Thermopolis(?) Shale. In the Lima Peaks a-ea, Dillon (1949) placed equivalent strata in the $F$-ar River Formation.

\section{MUDDY SANDSTONE, AND UPPER SANDSTONE OF THE FLOOD MEMBER OF THE BLACKLEAF FORMATION}

The Muddy Sandstone at Lincoln Mountain ir the Madison Range is composed of two yellowish-gr sen, crossbedded, thin-bedded sandstone units that are separated by a unit of mudstone. In a detailed sedimentological study of the Muddy in the Mad ‘ on 
Range, Vuke (1984) concluded that the strata were deposited, from base to top, in distal delta front, deltafront sheet sand, and distributary channel environments. The Muddy at the Greenhorn composite section, and its lithic equivalent in the Flood Member of the Blackleaf Formation in the western two sections, consists of quartz- and chertrich sandstone and interbedded mudstone deposited in fluvial, deltaic, and nearshore marine environments (Dyman and Nichols, 1988).

The Muddy Sandstone is $115 \mathrm{ft}(35 \mathrm{~m})$ thick at the Lincoln Mountain section. Vuke (1984) did not give thicknesses for this unit in the Madison Range, but we calculated a maximum thickness of about 85 ft $(26 \mathrm{~m})$ from her cross sections. Witkind (1969) estimated a thickness of $50 \mathrm{ft}(15 \mathrm{~m})$ for the Muddy(?) Sandstone in the southern part of the Madison Range, and it is $49 \mathrm{ft}(15 \mathrm{~m})$ thick at the Greenhorn composite section. In the area of the western two sections, the lithic equivalent of the Muddy ranges from 92 to $230 \mathrm{ft}(28$ to $70 \mathrm{~m})$ thick.

To our knowledge, no fossils have been identified from the Muddy in the Madison Range, but the shallow-water marine bivalve Ostrea anomioides Meek was reported by Hadley (1980) and Dyman and Nichols (1988) from the Greenhorn Range.

In the Madison Range, Austin and Stoever (1950) considered this unit to be part of the Aspen(?) Formation; Hall (1961) mapped the unit as the Muddy(?) Sandstone; Witkind (1969) mapped it as the Muddy(?) Sandstone Member of the Thermopolis(?) Shale; Hadley (1969a, 1980) considered it the upper unit of the Thermopolis Shale; Bolm (1969) considered the sandstone to be the Muddy Sandstone Member of the Thermopolis Formation; Lauer (1967), Ray (1967), Rose (1967), Wilson (1970), Kehew (1971), Walsh (1971), Vuke (1984), Tysdal and Simons (1985), and Tysdal (in press) used the formation name Muddy Sandstone.

In the Greenhorn Range and the northernmost parts of the contiguous Gravelly and Snowcrest Ranges, Mann (1954, 1960) described the stratigraphic unit here called Muddy and questionably assigned it to the "Colorado Formation." Hadley $(1960,1969 \mathrm{~b}, 1980)$ assigned the sandstone to the Thermopolis Shale, referring to it as the upper sandstone member in his early paper, but leaving it unnamed in his latter two publications. In the central Snowcrest Range, Gealy (1953) and Zeigler (1954) placed the sandstone in the upper part of the Thermopolis Formation. In the southern part of the Snowcrest Range, Keenmon (1950) did not describe a sandstone unit at the stratigraphic horizon of the unit, stating that rocks at the contact of the Bear River(?) and overlying Aspen(?) strata were poorly expo'ed. In the southern part of the Gravelly Range, cla stic rocks of the Muddy Sandstone were included witt the Aspen Formation by Sonderegger and others $\left(19^{\wedge} \mathrm{2}\right)$. In the Centennial Mountains, Kennedy (1947) did not distinguish a sandstone unit correlatable with the Muddy lithofacies. A sandstone that Witkind (1975, 1976) included with the Aspen(?) Formation may be the lithic equivalent of the Muddy Sandstone; Witlind (1982) stated that beds which he previously assigned to the Aspen(?) Formation may have been mappe t as Beaverhead(?) Formation. Honkala (1949) probably included this lithofacies within the Aspen Formation. In the Lima Peaks area, Dillon (1949) measured sirata that he assigned to the Bear River Formation; we consider a sandstone unit in the upper part of his section to be the upper sandstone of the Flod Member of the Blackleaf Formation.

\section{MOWRY SHALE}

The Mowry Shale is a bipartite formation in part of the region being considered in this report. It consists of a lower unit of pastel-colored bentoritic strata, called the Vaughn Member, and an upper unit of dark-gray mudstone. The Vaughn Member pinrhes out eastward in southwestern Montana and lilely intertongues with strata not readily discerned fom Mowry strata that overlie the Vaughn. Where the Vaughn Member is present such time-equiva'ent strata occur within the informal unit called the upper part of the Mowry; where the Vaughn is absent the time-equivalent rocks and strata of the upper part of the Mowry are grouped together as Mowry Shale undivided. The upper unit is present only in the Madison Range, although it may have been deposited farther west and subsequently eroded.

\section{Vaughn Member of Mowry Shale, and of Blackleaf Formation}

A sequence of light-colored bentonitic st ata overlies the Muddy Sandstone, and its lithic equivalent in the Blackleaf Formation, over a large area of southwestern Montana. In the Madison Range, Hall (1961) assigned the name "Albino" to the sequence of pastel beds and recognized that it was lithically similar to the Vaughn Member of the Blackleaf Formation in the area near Great Falls, Mont. The Albino name was never used beyond the range, however. Vaughn strata in the area of the type 
section are a lithic correlative of the Mowry Shale (Cobban and others, 1959). Tysdal and others (in press) assigned the name Vaughn Member to these strata in the Madison Range, and throughout a large area of southwestern Montana, and made the Vaughn a member of the Mowry Shale. Thus defined, the Vaughn is a member of both the Blackleaf Formation and the Mowry Shale.

In the Madison Range the Vaughn strata were deposited in a marsh environment according to Wilson (1970) and Vuke (1984); Wilson reported the brachiopod Lingula in the uppermost pastel strata, indicating some marine influence. In the area of the western two sections, Dyman and Nichols (1988) considered the pastel beds of the Vaughn Member as deposited in lacustrine to flood plain environments. The Vaughn Member is $270 \mathrm{ft}(82 \mathrm{~m})$ thick at Lincoln Mountain in the Madison Range, but it is absent from some other areas of the Madison Range. At the Lima Peaks section the unit is $885 \mathrm{ft}(271 \mathrm{~m})$ thick. The member has a maximum thickness of $1,240 \mathrm{ft}(378 \mathrm{~m})$ at the Antone Peak section, but poor exposures characterize the section; covered intervals could conceal a fault or faults that caused repetition of strata.

The name Mowry Shale was used by Reeside and Cobban $(1960$, p. 21,48$)$ to describe beds in the Madison Range that yielded pelecypod and fish fragments, but no description of a stratigraphic unit was given. Swanson was cited as providing the data, although post-Kootenai strata had not been subdivided by Swanson (1950). Austin and Stoever (1950) assigned these strata to the Aspen(?) Formation and, as noted above, Hall (1961) proposed the name "Albino" for the sequence of pastel beds. Lauer (1967), Ray (1967), Rose (1967), Kehew (1971), and Walsh (1971) used the name "Albino" for the pastel beds. Bolm (1969) used "Albino" for the pastel beds, and Wilson (1970) and Crabtree (1988) used "Albino" as a member of the Mowry Shale. Hadley (1969a, 1980) assigned the pastel beds to the Frontier Formation. Schwartz (1972) considered the pastel beds to be in the lower part of his lithofacies interval D. Vuke (1984), Tysdal and Simons (1985), and Tysdal (in press) assigned the pastel strata to the lower part of the Mowry Shale.

In an area about 10-12 $\mathrm{mi}(16-19 \mathrm{~km})$ north of the Lincoln Mountain section, Vuke (1984) reported that a lithic equivalent of the pastel beds in the Lincoln Mountain area is represented by a light-colored, 10-ft (0.3-m) thick volcaniclastic sandstone unit, which she placed in the uppermost part of the Muddy Sandstone. We agree that the two volcaniclastic sequences are correlative, but consider the light-colored sandstone in the northern exposures to be part of the Vaughn. The thickness of the light-colored volcaniclastic unit varies greatly throughout the range.

In the Greenhorn Range and the contiguous northern part of the Gravelly and Snowcrest Ran res, Mann $(1954,1960)$ assigned the pastel beds to the Colorado Formation. Klepper (1950, p. 69) assigned them to the Colorado Group and clearly recognized the possibility that they were a lateral equivalent of the Mowry Shale or perhaps the lower part of the Frontier Formation. Hadley $\left(1960,1969 \mathrm{~b}, 15^{\circ} \mathrm{O}\right)$ assigned the pastel beds to the Frontier Formation. In the central part of the Snowcrest Range, Gealy (1953) and Zeigler (1954) included the pastel beds in a unit called "undivided rocks of the Colorado and Montana groups" and "undifferentiated Colorado and Montana groups," respectively. In the southern part of the Snowcrest Range, Keenmon (1950) included the pastel lithologies within the Aspen(?) Format in. In the central part of the Gravelly Range, Sondererger and others (1982) placed the pastel beds and overl ring rocks (below the Upper Cretaceous Beaverhead Conglomerate) within the Aspen Formation. In the Centennial Mountains, Kennedy (1947) assigned all Cretaceous strata younger than the Bear River Formation to the Mesaverde Formation; such an assignment would include the pastel beds. Honkala's (1949) descriptions show that he assigned the pratel beds and immediately overlying rocks to the Arnen Formation, although he indicated that strata your rer than the pastel beds may be included within the unit as well. Witkind $(1975,1976)$ included the pestel beds and overlying strata within the Aspen(?) Formation; Witkind (1982) later stated that he may have mapped strata as Beaverhead(?) Formation that are beds which he previously assigned to the Aspen(?) Formation. Near Lima Peaks, Dillon (1949) plrced the pastel beds within the Aspen Formation.

Pastel beds in the Madison Range have yielded a Cretaceous megafloral assemblage, comporent identifications of which have been presented in Hall (1961), Wilson (1970), Vuke (1982), and Crabtree (1988). Smiley (in Wilson, 1970, p. 50) assigner an Albian age to this floral assemblage and Crabtree (1988) assigned a late Albian age to it. Wilson (1970, p. 50) reported the marine brachiopod Lingula from the uppermost pastel beds. The Albiar to Cenomanian(?) seed ferm Tempskya was collerted from the pastel beds at the Lima Peaks section (Dyman and Nichols, 1988). Two palynomorph assemblages from the pastel beds at the Lima Praks section yielded forms indicative of Cretaceous age (table 1). Although no further age refinement was possible, these assemblages are consistent vith 
assemblages in the Madison Range that are Albian in age.

\section{Upper part of Mowry Shale}

At Lincoln Mountain in the Madison Range, the Vaughn Member is overlain by $274 \mathrm{ft}(84 \mathrm{~m})$ of darkgray mudstone and silty mudstone that contain a few minor interbeds of sandstone, bentonite, and coal. These strata represent marine and marginal-marine deposits; marsh, stream channels, and overbank deposits are present according to Vuke (1984). No time-equivalent dark-gray mudstone strata are known in the area of the western three sections, although such strata may have been deposited and subsequently eroded prior to deposition of the Frontier Formation. The top of the Mowry in the Madison Range was chosen at the base of a sequence of chert-rich sandstone beds that aggregate about $50 \mathrm{ft}(15 \mathrm{~m})$ thick and which are placed in the Frontier Formation (Tysdal and Simons, 1985).

Strata of the upper part of the Mowry Shale, or Mowry undivided where pastel beds are absent in the Madison Range, were assigned to the Aspen(?) Formation by Austin and Stoever (1950). Hall (1961), Lauer (1967), Ray (1967), Kehew (1971), and Walsh (1971) mapped these rocks as Upper Cretaceous strata undivided. Bolm (1969) assigned the post-Vaughn strata to a unit of undifferentiated Cretaceous rocks, and Rose (1967) used "Albino" for them. Wilson (1970) assigned them to the Mowry Shale. Hadley (1969a, 1980) assigned strata of the upper member to the Frontier Formation. Schwartz (1972) considered them as part of his lithofacies interval D. Vuke (1984), Tysdal and Simons (1985), and Tysdal (in press) assigned the strata to the upper part of the Mowry Shale.

At Lincoln Mountain in the Madison Range, we obtained Albian palynomorphs from lower and upper beds of the upper member of the Mowry Shale, and Albian dinoflagellates from the upper beds (table 1). Wilson (1970, p. 50) reported dinoflagellates from the basal strata of the upper member, immediately above the pastel beds.

\section{FRONTIER FORMATION}

Strata assigned to the Frontier Formation differ in lithology and thickness from one section to the next. Lower strata of the Frontier are composed of lithic sandstone, conglomerate, bentonitic mudstone, and shale, and were deposited in fluvial and shallowmarine(?) environments. The lower strata contain palynomorphs of Cenomanian to Turonian age (t:ble 1).

The base of the Frontier Formation was placer at the base of the first sandstone unit above the dr-kgray mudstone of the Mowry Shale in the Madi 'on Range, and at the base of the first sandstone or conglomeratic bed above the Vaughn Member in the area of the other sections. At the Lima Penks section, about $30 \mathrm{ft}(9 \mathrm{~m})$ of dark-gray nonvolcr nic shale of Cenomanian age occurs above the Vaurhn Member of the Blackleaf Formation and below sandstone of the Frontier. Because lower Frontier sandstone and conglomerate beds are laterilly discontinuous in the Lima Peaks area, it is appropriate to place the base of the Frontier at the base of the shale, which also is a regional unconformity (Dyman and Nichols, 1988). The contact is probably diachronous, and correlation was best made where palynomorph data were available.

The long-ranging marine brachiopod Lingula subspatulata Hall and Meek was found in the brsal sandstone of the Frontier Formation at the Linc.ln Mountain section in the Madison Range and was associated with an unidentifiable juvenile ammonite. Basal strata of the Frontier in the Greenhorn composite section yielded the marine bivalve Pleurocardia pauperculum (Meek) (Dyman and Nichols, 1988).

\section{REFERENCES CITED}

Austin, W.H., and Stoever, E.C., Jr., 19:n, Reconnaissance geology of the south flank of Cinnamon Mountain, Gallatin Courty, Montana: Ann Arbor, University of Michiran M.S. thesis, $102 \mathrm{p}$.

Becraft, G.E., Kiilsgaard, T.H., and van Noy, R.M., 1970, Mineral resources of the Jack Creek Barin, Madison County, Montana: U.S. Geologinal Survey Bulletin 1319-B, 24 p.

Bolm, J.G., 1969, Geology of the Lone Mountain area, southwestern Montana: Moscnw, University of Idaho M.S. thesis, 38 p.

Brasher, G.K., 1950, The geology of part of the Snowcrest Range, Beaverhead County, Montrna: Ann Arbor, University of Michigan M.S. the ris, $58 \mathrm{p}$.

Christie, H.H., 1961, Geology of the southern part of the Gravelly Range, southwestern Montana: 
Corvallis, Oregon State University M.S. thesis, $159 \mathrm{p}$.

Cobban, W.A., Erdmann, C.E., Lemke, R.W., and Maughan, E.K., 1959, Revision of Colorado Group on Sweetgrass arch, Montana: American Association of Petroleum Geologists Bulletin, v. 43, p. 2786-2796.

1976. Type sections and stratigraphy of the members of the Blackleaf and Marias River Formations (Cretaceous) of the Sweetgrass arch, Montana: U.S. Geological Survey Professional Paper 974, 66 p.

Crabtree, D.R., 1988, Mid-Cretaceous ferns in situ from the Albino Member of the Mowry Shale, southwestern Montana: Palaeontographica, Abteilung B, v. 209, 27 p.

DeCelles, P.G., 1986, Sedimentation in a tectonically partitioned, nonmarine foreland basin--The Lower Cretaceous Kootenai Formation, southwestern Montana: Geological Society of America Bulletin, v. 97, p. 911-931.

Dillon, E.L., 1949, Stratigraphy of an area near Lima, Beaverhead County, Montana: Urbana, University of Illinois M.S. thesis, 103 p.

Dyman, T.S., 1985a, Preliminary chart showing stratigraphic correlation and lithofacies description for the Lower Cretaceous Blackleaf Formation and lower Upper Cretaceous Frontier Formation (lower part) in Beaverhead and Madison Counties, Montana: U.S. Geological Survey Open-File Report 85-729, 9 p., 1 pl.

$1985 \mathrm{~b}$, Measured stratigraphic sections of Lower Cretaceous Blackleaf Formation and lower Upper Cretaceous Frontier Formation (lower part) in Beaverhead and Madison Counties, Montana: U.S. Geological Survey Open-File Report 85-431, 72 p.

1985c, Stratigraphic and petrologic analysis of the Lower Cretaceous Blackleaf Formation and the Upper Cretaceous Frontier Formation (Lower part), Beaverhead and Madison Counties, Montana: Pullman, Washington State University Ph. D. dissertation, 230 p.

Dyman, T.S., Materna, W.L., and Wilcox, L.A., 1985, Stratigraphic applications of the Geologic Analysis System (GAS) [abs.]: American Association of Petroleum Geologists Bulletin, v. 69, p. 251.

Dyman, T.S., Niblack, Robert, and Platt, J.E., 1984, Measured stratigraphic section of Lower Cretaceous Blackleaf Formation and lower Upper Cretaceous Frontier Formation (lower part) near Lima, in southwest Montana: U.S. Geological Survey Open-File Report 84-838, 25 p.
Dyman, T.S., and Nichols, D.J., 1988, Stratigraphy of mid-Cretaceous Blackleaf and lower part of the Frontier Formations in parts of Beaverhead and Madison Counties, Montana: U.S. Geologiral Survey Bulletin 1773, $31 \mathrm{p}$.

Garihan, J.M., Schmidt, C.J., Young, S.W., and Williams, M.A., 1983, Geology and recurr?nt movement history of the Bismark-Spanish Peaks-Gardiner fault system, southwest Montana, in Lowell, J.D., Rocky Mountain foreland basins and uplifts: Rocky Mountain Association of Geologists, p. 295-314.

Gealy, W.J., 1953, Geology of the Antone Prak quadrangle, southwestern Montana: Cambridge, Mass., Harvard University Ph. D. dissertation, $143 \mathrm{p}$.

Hadley, J.B., 1960, Geology of the northern part of the Gravelly Range, Madison County, Montana, in Campau, D.E., and Anisgard, H.W., eds., West Yellowstone--Earthquake area: Billings Geological Society 11th Annual Field Conference Guidebook, p. 149-153.

1969a, Geologic map of the Cameron quadrangle, Madison County, Montana: U.S. Geological Survey Geologic Quadrangle Map GQ-813, scale 1:62,500.

$1969 \mathrm{~b}$, Geologic map of the Varney quadrangle, Madison County, Montana: U.S. Geologinal Survey Geologic Quadrangle Map GQ-814, scale 1:62,500.

1980, Geology of the Varney and Came-on quadrangles, Madison County, Montana: U.S. Geological Survey Bulletin 1459, 108 p.

Hall, W.B., 1961, Geology of part of the upner Gallatin Valley of southwestern Montana: Laramie, University of Wyoming Ph. D. dissertation, $239 \mathrm{p}$.

Holm, M.R., James, W.C., and Suttner, L.J., 1977, Comparison of the Peterson and Drarey Limestones, Idaho and Wyoming, and the calcareous members of the Kootenai Formation, western Montana, in Heisey, E.L., and others, eds., Rocky Mountain thrust belt, geology and resources: Wyoming Geological Association, 29th Annual Field Conference Guidebook, p. 259-270.

Honkala, F.S., 1949, Geology of the Centenrial region, Beaverhead County, Montana: A nn Arbor, University of Michigan Ph. D. dissertation, $145 \mathrm{p}$.

James, W.C., 1977, Origin of nonmarine-marine transitional strata at the top of the Kootenai Formation (Lower Cretaceous), southwest? 
Montana: Bloomington, University of Indiana Ph. D. dissertation, 281 p.

Karlstrom, R.N.V., 1948, Geology and ore deposits of the Hecla mining district, Beaverhead County, Montana: Montana Bureau of Mines and Geology Memoir 25, $87 \mathrm{p}$.

Keenmon, K.A., 1950, The geology of the BlacktailSnowcrest region, Beaverhead County, Montana: Ann Arbor, University of Michigan Ph. D. dissertation, $207 \mathrm{p}$.

Kehew, A.E., 1971, Environmental geology of part of the West Fork basin, Gallatin County, Montana: Bozeman, Montana State University M.S. thesis.

Kennedy, G.C., 1947, Preliminary report on the geology of a portion of the SE 1/4 Lyon quadrangle, Montana-Idaho: U.S. Geological Survey Open-File Report, 1 p., 1 pl., map scale $1: 21,000$.

Klepper, M.R., 1950, A geologic reconnaissance of parts of Beaverhead and Madison Counties, Montana: U.S. Geological Survey Bulletin 969C, p. 55-85.

Lauer, J.C., 1967, The stratigraphy and structure of the Snowflake Ridge area, Gallatin County, Montana: Corvallis, Oregon State University M.S. thesis, 165 p.

Lowell, W.R., 1965, Geologic map of the BannackGrayling area, Beaverhead County, Montana: U.S. Geological Survey Miscellaneous Geologic Investigations Map I-433, scale 1:31,680.

Mann, J.A., 1954, Geology of part of the Gravelly Range, Montana: Yellowstone-Bighorn Research Association, Contribution 190, 92 p. 1960, Geology of part of the Gravelly Range area, Montana, in Campau, D.E., and Anisgard, H.W., eds., West Yellowstone--Earthquake area: Billings Geological Society 11 th Annual Field Conference Guidebook, p. 114-127.

McBride, B.C., 1988, Geometry and kinematics of the central Snowcrest Range; a Rocky Mountain foreland uplift in southwestern Montana: Kalamazoo, Westem Michigan University M.S. thesis, $213 \mathrm{p}$.

Myers, W.B., 1952, Geology and mineral deposits of the northwest quarter of the Willis quadrangle and adjacent Browns Lake area, Beaverhead County, Montana: U.S. Geological Survey Open-File Report 52-105, 46 p.

Peale, A.C., 1896, Description of the Three Forks sheet (Montana): U.S. Geological Survey Atlas, Folio 24, $10 \mathrm{p}$.

Pearson R.C., and Zen, E-An, 1985, Geologic map of the eastern Pioneer Mountains, Beaverhead
County, Montana: U.S. Geological Survey Miscellaneous Field Studies Map MF-180 -A, scale 1:50,000.

Perry, W.J., Jr., 1986, Critical deep drillholes and indicated Paleozoic paleotectonic features north of the Snake River downwarp in southern Beaverhead County, Montana, and adjacent IC'?ho: U.S. Geological Survey Open-File Report 86$413,16 \mathrm{p}$.

Perry, W.J., Jr., Wardlaw, B.R., Bostick, N.H., and Maughan, E.K., 1983, Structure, burial his'ry, and petroleum potential of frontal thrust belt and adjacent foreland, southwest Montana: American Association of Petroleum Geologists Bulletin, v. 67, p. $725-743$.

Petroleum Information Corporation, 1984, Geologic Analysis System (GAS): Denver, Colo., Petroleum Information Corporation, Technical Services Training Manual, $195 \mathrm{p}$.

Ray, J.D., 1967, Structure and stratigraphy of the Cinnamon Mountain area, Gallatin Cornty, Montana: Corvallis, Oregon State Unive'sity M.S. thesis, $148 \mathrm{p}$.

Reeside, J.B., Jr., and Cobban, W.A., 1960, Str lies of the Mowry Shale (Cretaceous) and contemporary formations in the United Stater and Canada: U.S. Geological Survey Professional Paper 355, $126 \mathrm{p}$.

Richards, R.W., and Pardee, J.T., 1925, The Me'rose phosphate field, Montana: U.S. Geological Survey Bulletin 780-A, 32 p.

Roberts, A.E., 1965, Correlation of Cretaceous and lower Tertiary rocks near Livingston, Mon'æna, with those in other areas in Montana and Wyoming, in Geological Survey research, 1965: U.S. Geological Survey Professional Paper 525B, p. 54-63.

1972, Cretaceous and Early Tertiary depositional and tectonic history of the Livingston area, southwestern Montana: U.S. Geological Survey Professional Paper 52‘-C, $120 \mathrm{p}$.

Rose, R.R., 1967, Stratigraphy and structure of part of the southern Madison Range, Madison and Gallatin Counties, Montana: Corvallis, Origon State University M.S. thesis, 172 p.

Ruppel, E.T., O'Neill, J.M., and Lopez, D.A., 1983, Preliminary geologic map of the Dillon $1^{\circ} \times 2^{\circ}$ quadrangle, Montana: U.S. Geological Survey Open-File Report 83-168, scale 1:250,000.

Ryder, R.T., 1968, The Beaverhead Formation--A Late Cretaceous-Paleocene syntectonic deporit in southwestern Montana and east-central Idaho: 
University Park, Pennsylvania State University $\mathrm{Ph}$. D. dissertation, $153 \mathrm{p}$.

Ryder, R.T., and Ames, H.T., 1970, Palynology and age of Beaverhead Formation and their paleotectonic implications in Lima region, Montana-Idaho: American Association of Petroleum Geologists Bulletin, v. 54, p. 11551171.

Sadler, R.K., 1980, Structure and stratigraphy of the Little Sheep Creek area, Beaverhead County, Montana: Corvallis, Oregon State University M.S. thesis, 289 p.

Scholten, Robert, Keenmon, K.S., and Kupsch, W.O., 1955, Geology of the Lima region, southwestern Montana and adjacent Idaho: Geological Society of America Bulletin, v. 66, p. $345-404$.

Schwartz, R.K., 1972, Stratigraphic and petrographic analysis of the Lower Cretaceous Blackleaf Formation, southwestern Montana: Bloomington, Indiana University $\mathrm{Ph}$. $\mathrm{D}$. dissertation, $268 \mathrm{p}$.

1983, Broken Early Cretaceous foreland basin in S.W. Montana--Sedimentation related to tectonism, in Powers, R.B., ed., Geologic studies of the Cordilleran thrust belt: Denver, Colo., Rocky Mountain Association of Geologists, p. 159-183.

Sheedlo, M.K., 1984, Structural geology of the northern Snowcrest Range, Beaverhead and Madison Counties, Montana: Kalamazoo, Western Michigan University M.S. thesis, 132 p.

Skipp, Betty, Prostka, H.J., and Schleicher, D.L., 1979, Preliminary geologic map of the Edie Ranch quadrangle, Clark County, Idaho, and Beaverhead County, Montana: U.S. Geological Survey Open-File Report 79-845, scale $1: 62,500$.

Sonderegger, J.L., Berg, R.B., and Mannick, M.L., 1982, Geologic map of the northern part of the Upper and Lower Red Rock Lake quadrangles, Beaverhead and Madison Counties, Montana, in Sonderegger, J.L., Schofield, J.D., Berg, R.B., and Mannick, M.L., 1982, The upper Centennial Valley, Beaverhead and Madison Counties, Montana: Montana Bureau of Mines and Geology Memoir 50, $53 \mathrm{p}$.

Suttner, L.J., Schwartz, R.K., and James, W.C., 1981, Mesozoic to early Cenozoic foreland sedimentation in southwest Montana, in Tucker, T.E., ed., Field conference and symposium guidebook to southwest Montana: Montana Geological Society Guidebook, p. 93-103.
Swanson, R.W., 1950, Geology of a part of the Virginia City and Eldridge quadrangles, Montana: U.S. Geological Survey Open-File Report, 12 p.

Tysdal, R.G., in press, Geologic map of the Srhinx Mountain quadrangle and adjacent parts of the Cameron and Hebgen Dam quadran $l e s$, Montana: U.S. Geological Su-vey Miscellaneous Investigations Series Map I-1815, scale 1:62,500.

Tysdal R.G., Dyman, T.S., and Nichols, D.J., in press, Lower Cretaceous bentonitic stra ${ }^{+}$in southwestern Montana assigned to Va" ohn Member of Mowry Shale (east) and of Blac'leaf Formation (west): The Mountain Geologist.

Tysdal, R.G., and Simons, F.S., 1985, Geo'ngic map of the Madison Roadless Area, Gallatin and Madison Counties, Montana: U.S. Geological Survey Miscellaneous Field Studies Map MF1605-B, scale 1:96,000.

Veatch, A.C., 1907, Geography and geology of a portion of southwest Wyoming: U.S. Geological Survey Professional Paper 56, $178 \mathrm{p}$.

Vuke, S.M., 1982, Depositional environments of the Cretaceous Thermopolis, Muddy and Mowry Formations, southern Madison and Gallatin Ranges, Montana: Missoula, University of Montana M.S. thesis, 141 p. 1984, Depositional environments of the Early Cretaceous western interior seawar" in southwestern Montana and the northern U-ited States, in Stott, D.F., and Glass, D.J., eds. The Mesozoic of middle North America: Canadian Society of Petroleum Geologists Memoir 9, p. 127-144.

Walsh, T.H., 1971, Quaternary geology of the east portion of West Fork basin, Gallatin Cornty, Montana: Bozeman, Montana State University M.S. thesis.

Wilson, M.D., 1970, Cretaceous stratigraphy of the southern Gallatin and Madison Ranges: Moscow, University of Idaho Ph. D. dissertition, $86 \mathrm{p}$.

Witkind, IJJ., 1969, Geology of the Tepee Creek quadrangle, Montana-Wyoming: U.S. Geological Survey Professional Paper 609, 101 p.

1975, Geology of a strip along the Centennial fault, southwestern Montana and adjacent I 1 aho: U.S. Geological Survey Miscellareous Investigations Series Map I-890, scale 1:62 500. 1976, Geologic map of the southern part of the Upper Red Rock Lake quadrangle, southwrstem Montana and adjacent Idaho: U.S. Geolroical 
Survey Miscellaneous Investigations Series Map I-943, scale 1:62,500.

1982, Geologic map of the Centennial Mountains Wilderness Study Area and contiguous areas, Idaho and Montana: U.S. Geological Survey Miscellaneous Field Studies Map MF-1342-A, scale 1:50,000.

Witkind, IJ., and Prostka, H.J., 1980, Geologic map of the southern part of the Lower Red Rock Lake quadrangle, Beaverhead and Madison Counties, Montana, and Clark County, Idaho: U.S.
Geological Survey Miscellaneous Investigstions Series Map I-1216, scale 1:62,500.

Zeigler, J.M., 1954, Geology of the Blacktail area, Beaverhead County, Montana: Cambridge, Mass., Harvard University Ph. D. dissertrtion, $147 \mathrm{p}$.

Zen, E-an, 1988, Bedrock geology of the Vipond Park 15-minute, Stine Mountain 7 1/2-minute, and Maurice Mountain 7 1/2-minute quadrangles, Pioneer Mountains, Beaverhead Connty, Montana: U.S. Geological Survey Bulletin $1625,49 \mathrm{p}$.

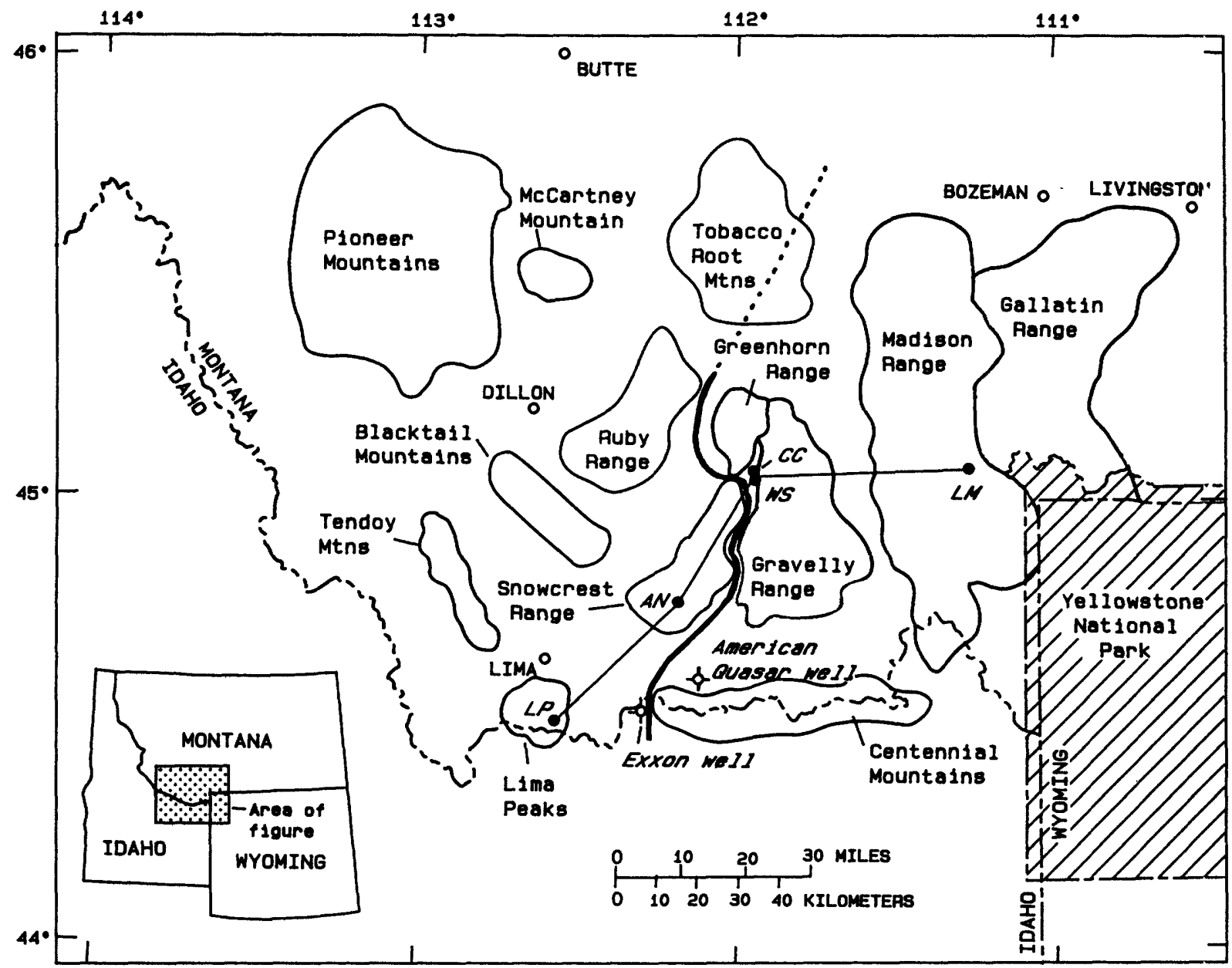

Figure 1.--Index map of southwestern Montana showing mountain ranges, locations of measured sections, and line (bold) marking geographic position of change in nomenclature of Lower Cretaceous rocks. Bold line is dotted where no Cretaceous rocks are preserved. Abbreviations for measured sections are as follows: AN, Antone Peak; $\mathrm{C}$ ?, Cow Camp; LM, Lincoln Mountain; LP, Lima Peaks; WS, Warm Springs Creek. 


\begin{tabular}{|c|c|c|c|c|c|c|c|c|}
\hline \multicolumn{2}{|c|}{ AGE } & \multicolumn{2}{|c|}{$\begin{array}{c}\text { NORTHWESTERN } \\
\text { MONTANA }\end{array}$} & \multicolumn{4}{|c|}{$\begin{array}{c}\text { SOUTHWESTERN MONTANA } \\
\text { (THIS REPORT) }\end{array}$} & $\begin{array}{l}\text { NORTHWESTE:AN } \\
\text { WYOMING }\end{array}$ \\
\hline 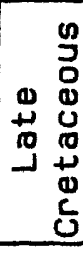 & 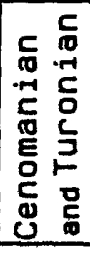 & \multicolumn{2}{|c|}{$\begin{array}{c}\text { Marias Aiver } \\
\text { Shale } \\
\text { (part) }\end{array}$} & \multicolumn{2}{|c|}{$\begin{array}{l}\text { Frontier } \\
\text { Formation } \\
\text { (part) }\end{array}$} & \multicolumn{2}{|c|}{$\begin{array}{l}\text { Frontier } \\
\text { Formation } \\
\text { (part) }\end{array}$} & $\begin{array}{l}\text { Frontier } \\
\text { Formaticn } \\
\quad \text { (part) }\end{array}$ \\
\hline \multirow{5}{*}{ 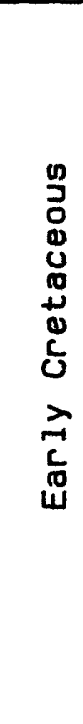 } & \multirow{4}{*}{ 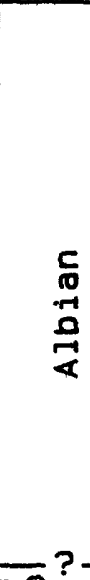 } & \multirow{4}{*}{ 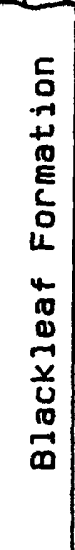 } & $\underbrace{\text { Boot legger }}_{\substack{\text { Vaughn } \\
\text { Member }}}$ & \multirow{4}{*}{ 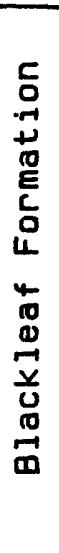 } & $\begin{array}{l}\text { Vaughn } \\
\text { Member }\end{array}$ & 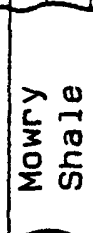 & $\begin{array}{l}\text { Upper } \\
\text { part }\end{array}$ & $\begin{array}{l}\text { Mowry } \\
\text { Shale }\end{array}$ \\
\hline & & & $\begin{array}{l}\text { Taft } \mathrm{HiIl} \\
\text { Member }\end{array}$ & & \multirow{3}{*}{$\begin{array}{l}\text { Flood } \\
\text { Member }\end{array}$} & \multicolumn{2}{|c|}{$\begin{array}{l}\text { Muddy } \\
\text { Sandstone }\end{array}$} & $\begin{array}{l}\text { Muddy } \\
\text { Sandstone }\end{array}$ \\
\hline & & & \multirow{2}{*}{$\begin{array}{l}\text { Flood } \\
\text { Member }\end{array}$} & & & \multirow{2}{*}{ 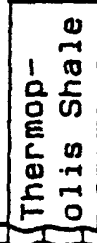 } & $\begin{array}{l}\text { Shale } \\
\text { member }\end{array}$ & $\begin{array}{l}\text { Thermopolis } \\
\text { Shale }\end{array}$ \\
\hline & & & & & & & $\begin{array}{l}\text { Sandstone } \\
\text { member }\end{array}$ & Cloverly \\
\hline & 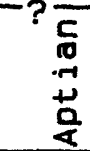 & \multicolumn{2}{|c|}{$\begin{array}{l}\text { Kootenai } \\
\text { Formation }\end{array}$} & \multicolumn{2}{|c|}{$\begin{array}{l}\text { Kootenai } \\
\text { Formation }\end{array}$} & \multicolumn{2}{|c|}{$\begin{array}{l}\text { Kootenai } \\
\text { Formation }\end{array}$} & Forination \\
\hline
\end{tabular}

Figure 2.--Correlation chart of Lower Cretaceous rocks in westem Montana and northwestern Wyoming. 


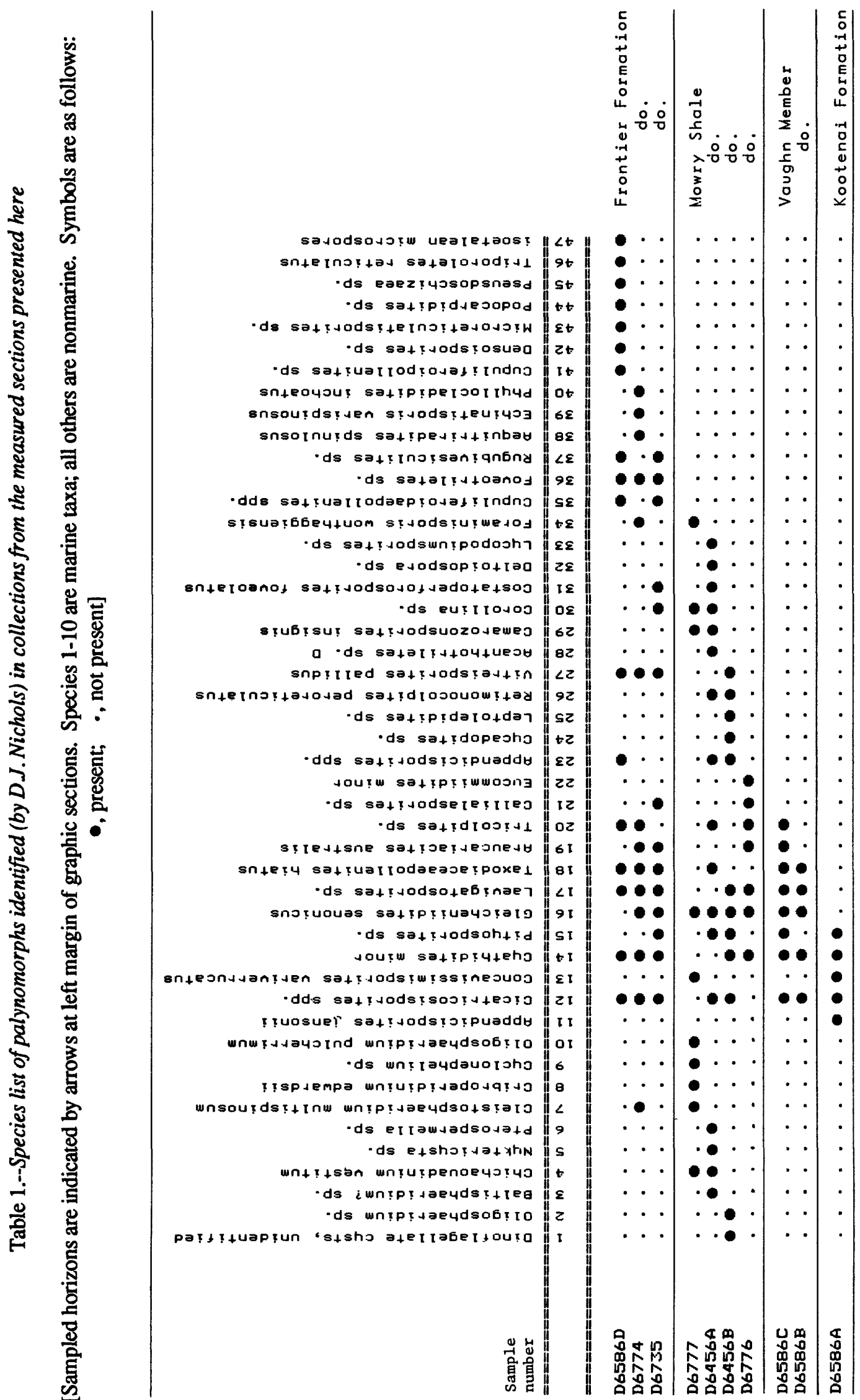


Table 2.--Alphabetized list of species. Index number corresponds to row number in table 1

\begin{tabular}{|c|c|}
\hline Number & Species \\
\hline 28 & Acanthotriletes sp. D \\
\hline 38 & Aequitriradites spinulosus \\
\hline 11 & Appendicisporites jansoni $i$ \\
\hline 23 & Appendicisporites spp. \\
\hline 19 & Araucariacites australis \\
\hline 3 & Bal ti sphaeridium? sp. \\
\hline 21 & Callial asporites sp. \\
\hline 29 & Camarozonsporites insignis \\
\hline 4 & Chichaouadinium vesti tum \\
\hline 12 & Cicatricosisporites spp. \\
\hline 7 & Cleistosphaeridium multispinosum \\
\hline 13 & Concavissimisporites variverrucatus \\
\hline 30 & Corollina sp. \\
\hline 31 & Costatoperforosporites foveolatus \\
\hline $\mathbf{8}$ & Cribroperidinium edwardsii \\
\hline 35 & Cupul i feroi daepol leni tes spp. \\
\hline 41 & Cupul i feroipol lenites sp. \\
\hline 14 & Cyathidites minor \\
\hline 24 & Cycadopi tes sp. \\
\hline 9 & Cycl onephel i um sp. \\
\hline 32 & Del toi dospora sp. \\
\hline 42 & Densoi sporites sp. \\
\hline 1 & Dinof lagel late cysts, unidentified \\
\hline 39 & Echinatisporis varispinosus \\
\hline 22 & Eucommi idites minor \\
\hline 34 & Foraminisporis wonthaggiensis \\
\hline 36 & Foveotriletes sp. \\
\hline 16 & Gleicheni idites senonicus \\
\hline 17 & Laevi qatosporites $s p$. \\
\hline 25 & Leptolepidites sp. \\
\hline 33 & Lycopodiumsporites sp. \\
\hline 43 & Microreticulatisporites sp. \\
\hline 5 & Nyktericysta sp. \\
\hline 10 & 01 igosphaeridium pulcherrimum \\
\hline 2 & Ql igosphaeridium $5 p$. \\
\hline 40 & Fhyllocladidites inchoatus \\
\hline 15 & Pityosporites sp. \\
\hline 44 & Podocarpidites 50 . \\
\hline 45 & Pseusdoschizaea sp. \\
\hline 6 & Pterospermel la sp. \\
\hline 26 & Retimonocolpites peroreticul atus \\
\hline 37 & Rugubivesiculites sp. \\
\hline 18 & Taxodi aceaepollenites hiatus \\
\hline 20 & Tricolpites sp. \\
\hline 46 & Triporoletes reticul atus \\
\hline 27 & Vitrei sporites pallidus \\
\hline 47 & isoetalean microspores \\
\hline
\end{tabular}

